\title{
Léčba pacientů s chronickou myeloidní leukemií - nečekaný anebo očekávaný průnik onkologie a vnitřního lékařství?
}

\section{Daniela Žáčková \\ Interní hematologická a onkologická klinika LF MU a FN Brno, pracoviště Bohunice}

K práci Slezáková K et al. Súčasné možnosti liečby BCR-ABL1 pozitívnej chronickej myelocytovej leukémie u dospelých pacientov. Vnitř Lék 2020; 66(4): 214-224.

Zavedení specifických inhibitorů tyrozinkinázy (TKI) do terapie pacientů s chronickou myeloidní leukemií (CML) před téměř 20 lety vedlo k zásadní proměně do té doby fatálního nádorového onemocnění s mediánem přežití pohybujícím se v rozmezí 3-5 let v dobře zvladatelné chronické onemocnění nezkracující očekávanou délku života (1). Vskutku revoluční změna v terapeutickém př́istupu k pacientům s CML přesáhla hranice hematologické onkologie a cílená léčba pomocí perorálně uživaných tablet TKI, prodlužujících prežití na úroveň celkové populace, se stala paradigmatem pro léčbu nádorových onemocnění jako takových. Původní predstava o dlouhodobé až celoživotně podávané terapii, motivovaná obavou z relapsu onemocnění při prokázané rezistenci leukemických kmenových buněk vůči působení TKI, vzala za své poté, co se v řadě studií podařilo u některých pacientů dosahujících hluboké molekulární remise léčbu kontrolovaně vysadit (2-5). Dosažení stavu remise bez nutnosti trvalého užívání léků (tretament-free remission - TFR) se tak stalo novým cílem léčby pacientů s CML, blížíím se úplnému vyléčení z nádorového onemocnění.

I přes nesporné úspěchy a nebývalý pokrok na poli léčby CML zůstává stále ještě celá řada nevyrešených otázek. Samotné setrvalé TFR je dosahováno u zhruba jen 50 \% pacientů, kteří se o vysazení pokusí. U ostatních pacientů je po zpravidla pouze molekulárním návratu nemoci léčba obnovována s jen hypotetickou šancí na dalši vysazení, soustředěnou do omezeného okruhu pouze několika klinických studií. Klíč k úspěchu dosažení setrvalé TFR stále není znám i preses extenzivní snahu o odhalení potenciálních prediktivních faktorů. Nejvíce bodů dosud nasbíraly délka předchozí léčby TKI a délka trvání hluboké remise před vysazením, nicméně robustní prediktor, at už klinický či biologický, stále chybí. Třebaže se pokusy o vysazení TKI jeví poměrně bezpečnými ve smyslu velmi rychlého obnovení velké molekulární remise u téměř všech pacientů po opětovném zahájení užívání TKI a nepř́itomnosti obávané progrese do pokročilých fází onemocnění, stále nevíme, jaký bude osud pacientů po delší době od vysazení. Velmi pozdní návraty onemocnění nelze spolehlivě vyloučit vzhledem k sice ojedinělým, ale jasně prokázaným relapsům CML i mnoho let po úspěšně provedené alogenní transplantaci krvetvorných buněk (6). Poměrně záhy po vysazení můžeme čelit původně nečekaným problémům v podobě kloubně-svalových bolestí, označovaných jako syndrom z vysazení TKI (TKI withdrawal syndrome - TWS) a postihujících až 1/3 pacientů vysazujících léčbu. A konečně, zcela zásadní limitací vysazování je fakt, že úspěšného vysazení TKI dosáhne méně než $20 \%$ ze všech pacientů s CML.

Naprostá většina pacientů tedy vyžaduje léčbu dlouhodobou, účinnou a zejména dobře snášenou. Právě tolerance léčby, či naopak výskyt jejích nežádoucích účinků (Nú) vystupují v kontextu dlouhodobé terapie do popředí zájmu. Autoři Slezáková et al. ve svém přehledovém článku přinášejí ucelený a podrobný přehled současných možností léčby CML s důrazem kladeným na předložení důkazů o účinnosti jednotlivých prípravků nejen ve studiích, ale i v klinické praxi. Neméně prostoru pak věnuji výskytu a řešení jednotlivých projevů nesnášenlivosti (7). Pokud se typický cílový čtenář časopisu Vnitřní lékařství necítí zcela komfortně při četbě pasáží o významu pravidelného monitorování hladiny BCRABL1 transkriptů pomocí speciálních citlivých vyšetřovacích metod či se ztrácí ve výčtu podílů různých typů léčebných odpovědí dosahovaných jednotlivými TKI, při popisu Nú se rázem ocitá ve známých vodách veskrze interní terminologie. Pokud pomineme sice obtěžující, často dlouhodobě přetrvávající a kvalitu života negativně ovlivňující Nú prototypu TKI imatinibu, jakými jsou např. bolesti a křeče svalů, únava, otoky víček či dyspeptické obtíže, které ale nikterak nenaruší aureolu imatinibu coby nejbezpečnějšího preparátu z řady TKI, pozornost se upíná zejména k NÚ TKI vyšších generací, které mohou být velmi závažné až život ohrožující. Jak opakovaně zdůrazňuje Slezáková et al, jsou to jednak poměrně časté, až u 1/3 pacientů se objevující pleurální výpotky a naštěstí vzácná, ale závažná plicní arteriální hypertenze, které provázejí léčbu dasatinibem, a dále pak arteriální uzávěry v podobě ischemické choroby dolních končetin, cévních mozkových príhod a ischemické choroby srdeční popisované ve zvýšené míre při léčbě ponatinibem a nilotinibem, který navíc negativně ovlivňuje metabolismus glukózy a lipidů (8-11). 
Podobně jako TWS po vysazení TKI, ani zmíněné NÚ TKI vyšších generací nebyly zcela očekávané a na to konto ve studiích dostatečně ošetřené. Až delší sledování pacientů přineslo alarmující informace: pleurální výpotky se mohou objevit i po několika letech dosud bezproblémové a zpravidla velmi účinné terapie dasatinibem, incidence cévních Nú během léčby nilotinibem narůstá v čase a analogické Nú léčby ponatinibem byly tak časté a závažné, že dokonce dočasně vyřadily prípravek z amerického trhu, vedly k pozastavení studie fáze Il a kúplnému ukončení studie fáze III v první linii léčby. Nové skutečnosti indukovaly řadu kroků směřujicích ke zmírnění výskytu a závažnosti Nú při zachované účinnosti. Dưraz je kladen už na samotnou selekci pacientů, resp. volbu prípravku pro toho kterého pacienta s ohledem na individuální profil Nú preparátu a již prítomné komorbidity a rizikové faktory na straně pacienta. Během rozhodovacího procesu, jaký zvolit lék, jsou mezi všemi hledisky, jak je popisují autoři v komentovaném článku, právě tyto zmíněné faktory těmi nejzásadnějšími. Hematolog tak nezbytně vystupuje za hranice svého oboru a minimálně se vrací ke svým interním základům, či mnohem lépe, navazuje mezioborovou spolupráci s dalšími specialisty nejen na poli interní medicíny, aby si pacienta s jejich pomocí prè nasazením léčby rádně prověřil a na základě vyhodnocení všech rizik zvolil co nejvhodnější prípravek. Osamocen by neměl zůstat ani v průběhu terapie, kdy kromě monitorování efektivity léčby nesmí opomenout pravidelně vyhodnocovat její toleranci a na případné negativní jevy včas a erudovaně reagovat. Pomůckou při sledování pacientů mohou být množíci se publikace mezioborových doporučení pro sledování a zvládání již prítomných komplikací, a stejně tak pro účinnou prevenci jejich výskytu $(12,13)$.

Z výše uvedeného může vzniknout dojem, že léčba pacientů s CML osciluje mezi dvěma krajními póly - celoživotní léčbou, zatíženou kromě rizika závažných Nú také negativním dopadem na kvalitu života, ekonomickou náročností a psychologickou zátěží každodenní připomínky existence nádorového onemocnění, a úplným vysazením terapie, kterého dosáhne jen malý podíl pacientů a ze kterého dosud není sňato riziko pozdních relapsủ či syndromu z vysazení. Jedním z perspektivních kroků balancujících mezi účinností a tolerancí se jeví optimalizace dávek TKI, at již ve smyslu jejich redukce či volby intermitentního dávkovacího schématu. Standardní doporučené dávky TKI zpravidla vzešly z farmakokinetických dat a výsledků malých studií fáze I, aby následně byly modifikovány na základě výsledků dalších studií či experimentálních průkazů, že pro účinnost TKI je zásadní jejich intracelulární retence, nikoliv dlouhodobá expozice vydatným plazmatickým hladinám léků (14). V současné době již máme důkazy o účinnosti i velmi nízkých či intermitentně podávaných dávek TKI s významným bonusem ve snížení výskytu Nú (15-17). Výborné výsledky dosažené v britské studii DESTINY, ve které byla dávka TKI zredukována na polovinu po dobu jednoho roku před vlastním kompletním vysazením, naznačují jeden z dalších možných směrů optimalizace rovnováhy mezi účinností a bezpečností léčby včetně jejího vysazení (18). V současné době je v ČR v procesu schvalování akademická studie HALF, která si klade za cíl zhodnotit v unikátním celonárodním měřítku úspěšnost a bezpečnost vysazení TKI po předchozí postupné redukci dávky. Za realizační tým doufám, že ambiciózní projekt přispěje cennou informací do mozaiky vědění na poli léčby CML a zvýší naději na nalezení co nejoptimálnější strategie pro dlouhodobý management pacientů, které již dávno primárně neohrožuje jejich nádorové onemocnění, ale komplikace a rizika zpravidla dlouhodobě užívané terapie.

\section{LITERATURA}

1. Bower H, Björkholm M, Dickman PW, et al. Life Expectancy of Patients With Chronic Myeloid Leukemia Approaches the Life Expectancy of the General Population. J Clin Oncol 2016; 34: 2851-2857.

2. Mahon FX, Réa D, Guilhot J, et al. Discontinuation of imatinib in patients with chronic myeloid leukaemia who have maintained complete molecular remission for at least 2 years: the prospective, multicentre Stop Imatinib (STIM) trial. Lancet Oncol 2010; 11: 1029-1035. 3. Rousselot P, Charbonnier A, Cony-Makhoul P, et al. Loss of major molecular response as a trigger for restarting tyrosine kinase inhibitor therapy in patients with chronic-phase chronic myelogenous leukemia who have stopped imatinib after durable undetectable disease. J Clin Oncol 2014; 32: 424-430

4. Saussele S, Richter J, Guilhot J, et al. Discontinuation of tyrosine kinase inhibitor therapy in chronic myeloid leukaemia (EURO-SKI): a prespecified interim analysis of a prospective, multicentre, non-randomised, trial. Lancet Oncol 2018; 19: 747-757.

5. Hochhaus A, Masszi T, Giles FJ, et al. Treatment-free remission following frontline nilotinib in patients with chronic myeloid leukemia in chronic phase: results from the ENESTfreedom study. Leukemia 2017; 31: 1525-1531.

6. Sekhri A, Liu D, Rasul M, et al. Very late relapse of chronic myelogenous leukemia after allogeneic bone marrow transplantation. Leuk Res 2009; 33: 1291-1293.

7. Slezáková K, Mistrík M, Bátorová A. Súčasné možnosti liečby BCR-ABL1 pozitívnej chronickej myelocytovej leukémie u dospelých pacientov. Vnitř Lek 2020; 66(4): 214-224.

8. Cortes JE, Saglio G, Kantarjian HM, et al. Final 5-Year Study Results of DASISION: The Dasatinib versus Imatinib Study in Treatment-Naïve Chronic Myeloid Leukemia Patients Trial. J Clin Oncol 2016; 34: 2333-2340.

9. Cortes JE, Kim DW, Pinilla-lbarz J, et al. Ponatinib efficacy and safety in Philadelphia chromosome-positive leukemia: final 5-year results of the phase 2 PACE trial. Blood 2018; 132: 393-404.

10. Hochhaus A, Saglio G, Hughes TP, et al. Long-term benefits and risks of frontline nilotinib vs imatinib for chronic myeloid leukemia in chronic phase: 5-year update of the randomized ENESTnd trial. Leukemia 2016; 30: 1044-1054.

11. Racil Z, Koritakova E, Sacha T, et al. Insulin resistance is an underlying mechanism of impaired glucose metabolism during nilotinib therapy. Am J Hematol 2018; 93: E342-E345. 12. Medeiros BC, Possick J, Fradley M. Cardiovascular, pulmonary, and metabolic toxicities complicating tyrosine kinase inhibitor therapy in chronic myeloid leukemia Strategies for monitoring, detecting, and managing. Blood Rev 2018; 32: 289-299.

13. Steegmann JL, Baccarani M, Breccia M, et al. European LeukemiaNet recommendations for the management and avoidance of adverse events of treatment chronic myeloid leukaemia. Leukemia 2016; 30: 1648-1671.

14. Simara P, Stejskal S, Koutna I, et al. Apoptosis in chronic myeloid leukemia cells transiently treated with imatinib or dasatinib is caused by residual BCR-ABL kinase inhibition. Am J Hematol 2013; 88: 385-393.

15. Faber E, Divoká M, Skoumalová l, et al. A lower dosage of imatinib is sufficient to maintain undetectable disease in patients with chronic myeloid leukemia with long-term low-grade toxicity of the treatment. Leuk Lymphoma 2016; 57: 370-375.

16. La Rosée P, Martiat P, Leitner A, et al. Improved tolerability by a modified intermittent treatment schedule of dasatinib for patients with chronic myeloid leukemia resistant or intolerant to imatinib. Ann Hematol 2013; 92: 1345-1350.

17. Naqvi K, Jabbour E, Skinner J, et al. Early results of lower dose dasatinib (50 mg daily) as frontline therapy for newly diagnosed chronic-phase chronic myeloid leukemia. Cancer 2018; 124: 2740-2747.

18. Clark RE, Polydoros F, Apperley JF, et al. De-escalation of tyrosine kinase inhibitor dose in patients with chronic myeloid leukaemia with stable major molecular response (DESTINY): an interim analysis of a non-randomised, phase 2 trial. Lancet Haematol 2017; 4: e310-e316. 